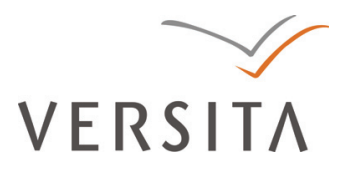

\title{
CONDITIONS OF BIOMASS PRODUCTION \\ FOR ENERGY GENERATION PURPOSES IN POLAND
}

\author{
Stanisław Bielski, Ph.D. Eng. \\ Department of Agrotechnology and Crop Management \\ Faculty of Environmental Management and Agriculture \\ University of Warmia and Mazury in Olsztyn \\ Oczapowskiego 8, 10-718 Olsztyn \\ e-mail: stanislaw.bielski@uwm.edu.pl
}

Received 30 June 2011, Accepted 3 August 2011

\begin{abstract}
The issue of production of raw materials for energy generation on agricultural areas is a multileveled issue (the economic, social, environmental and other aspects should be considered). Plantations of energetic plants that represent an important component in satisfying the increasing demand for biomass resulting from the requirement of increasing the use of renewable energy sources in Poland and the European Union will be an important aspect in production of agricultural biomass during the nearest future. Agroenergetics should result in a significant development of agriculture. This paper aims at presenting the legal-economic and technological conditions of biomass production for energy generation purposes as concerns liquid biofuels (as a substitute for fuels produced on the base of crude oil) and solid biomass (used in heat and power generation). This is a consequence of high emissions of greenhouse gases from transport end heat and power generation sectors.
\end{abstract}

Keywords: biomass, renewable energy, liquid biofuels, legal regulations.

JEL classification: Q27. 


\section{Introduction}

Availability of easily transmitted energy contributed to rapid industry development. For many decades the people had not taken care for either reasonable management of the decreasing (during the recent years quite rapidly) resources of non-renewable energy carriers (coal, crude oil and gas) or the consequences for the natural environment and human health resulting from their use. The current generation is paying the bill for irrational use of the natural resources and disregard for the environment quality. The price for the resources mismanagement will also be paid by the following generations. It is the obvious fact that the resources of non-renewable fuels are decreasing. According to various projections their availability will continue for 40-150 years. At the same time the pollutions generated by combustion of fossil fuels have become a global problem ${ }^{1}$.

Projections indicate that by the year 2020 energy consumption will increase by ca. $60 \%{ }^{2}$ Energy consumption increase results in the increased GHG (greenhouse gases) emissions to the atmosphere, which has negative consequences for climatic changes. The analysts highlight the high probability of energy crisis development and the differences observed concern its time only. It is expected within the coming 15-25 years ${ }^{3}$. The global increase in demand for energy (particularly in China, India and Brazil) should be satisfied not only by coal, crude oil and natural gas, but also by the renewable energy sources available in many different forms ${ }^{4}$ The renewable energy sources include, first of all the energy of the sun, wind, flowing waters, geothermal as well as the energy accumulated in the form of biomass ${ }^{5}$. In numerous scientific researches and expert opinions the thesis dominates that biomass is and will be the energy carrier with dominating volume among renewable energy sources in Poland. Utilisation of biomass is actually nothing else but utilisation of solar energy assimilated by plants in the process of accumulation of carbon in the tissues ${ }^{6}$.

Timber from the forests, orchards, special plantations of fast-growing trees (e.g. energetic willow) and waste of timber industry, plants cultivated for energetic purposes: seeds of seeds of oil bearing plants processed into esterified oils that are used as fuels, bulbs of potatoes, roots of beets, grains of cereals and cereal plants processed into ethyl alcohol added to car fuels, organic residues and waste - straw and other agricultural residues that are waste materials from agricultural production, waste produced in agricultural-food industry, organic municipal waste and organic industrial waste (cellulose - paper industry) are classified as the most important sources of biomass ${ }^{7}$. Biomass may be used for energy generation purposes in the processes of direct combustion of solid biofuels or simultaneous combustion of biomass with coal in 
existing energetic boilers (timber, straw, energetic plants, sewage sediments, others), processing into liquid fuels (rapeseed oil esters, ethanol, methanol) or gaseous fuels (agricultural biogas, gas from sewage treatment plants, landfill gas). The chemical composition determines the way of biomass processing into energy carriers. Processing of biomass into energy carriers may be achieved by physical, chemical or biochemical methods.

The renewable energy sources are, to a significant extent, of local character; they are not dependent on availability of conventional energy sources in the future and their mainly decentralised nature limits the susceptibility of the economy on variability in energy supplies. Given that there are no doubts that renewable energy is the key element of the sustainable energetic future $^{8}$. The energy, ecological and regional policy of the European Union gave high priority to renewable energy sources. Poland as a Member State of the European Union committed itself to develop the appropriate system for support of the renewable energy sources development and takes active position in creating the Community energy policy. As a consequence of the above, energy efficiency improvement, energy safety improvement, development of renewable energy use, development of competitive markets for fuels and energy, limiting the influence of the energy sector on the environment represent the fundamental directions in the Polish energy policy ${ }^{9}$.

This paper aims at presenting the legal-economic and technological conditions of biomass production for energy generation purposes as concerns liquid biofuels (as a substitute for fuels produced on the base of crude oil) and solid biomass (used in heat and power generation).

\section{Legal-economic conditions concerning biomass use and processing}

The legal requirements include regulations concerning, among others, the environment protection that are correlated with the increasing limitations in use of fossil fuels and shift to the renewable energy sources. In the Kyoto Protocol the maximum emissions limits (computed as $\mathrm{CO}_{2}$ equivalent) for the years 2008-2012 and the main parties guilty of the greenhouse effect were specified. The signatories of Kyoto Protocol committed themselves to reduce emissions of greenhouse gases. That required establishing legal regulations aiming at, among others, increasing the share of renewable fuels in the energy balance of individual countries, and regions and, as a consequence, the entire planet ${ }^{10}$. The White Paper: Energy for the future - renewable energy sources, plays the key role in the development of renewable energy policy. That document aimed at indicating the necessity for increasing the share of energy from renewable sources in the fuels and energy balance of the European Union (to reach 12\% share of renewable energy 
in the total primary energy consumption in the European Union by 2010). The White Paper defined numerous instruments increasing the share of the renewable energy sources in the energy balance of the European Union to establish appropriate market conditions for development of renewable energy sources, such as application of favourable fiscal and financial instruments (tax credits, subsidies) as well as strengthening the role of renewable energy sources in the policies, framework programmes and budgets. The Green Paper 'Towards a European strategy for the security of energy supply' of 2000 should also be mentioned. That document defined the increase in the share of renewable energy sources in the total generation of energy to $12 \%$ by and to $22 \%$ in electric power generation.

The Directive 2003/30/EC of the European Parliament and of the Council of 8 May 2003 on the promotion of the use of biofuels or other renewable fuels for transport was the fundamental legal act on the basis of which the domestic acts securing its complete transposition into the Polish law i.e. the Acts of 25 August 2006 on biocomponents and liquid biofuels and on the system of fuels quality monitoring and control were drafted. Those acts introduced numerous changes into the Polish law that were focused on creating favourable and lasting conditions for development of the market of biocomponents and liquid biofuels. The most important changes concerned creating the possibilities for production by individual farmers of all liquid biofuels that were their own fuels for their own use, introduction as of the $1^{\text {st }}$ of January 2008 of the requirement for assuring a specific share of biocomponents in the transport fuels' market while the implementation of the term of "chosen fleet" in the Polish law made use of a wide range of liquid biofuels other than allowed for general trading characterised by high contents of biocomponents in the vehicles and machines belonging to the "chosen fleets" possible".

The Multiyear programme of promotion of biofuels and other renewable fuels for the years 2008-2014 represents performance of article 37 of the Act of the 25 th of August 2006 on biocomponents and liquid biofuels. It presents the mechanisms of support for production of biocomponents as concerns the tax system, and in particular the exemption from the excise tax, corporate income tax and fuel charge. It drafts the possibilities of support for cultivation of energetic plants representing raw material for production of biocomponents and investments in production of biocomponents and liquid fuels from the European Union funds and the domestic public funds. That document presents the activities aiming at increasing the demand for liquid biofuels as well as drafts the frameworks for scientific-research and information-educative activities in that field.

At the Department of Energy of the Ministry of Economy the works are in progress on the new version of the Multiyear programme of promotion of biofuels and other renewable fuels for 
the years 2008-2014. The Multiyear programme... was to support the mechanisms of sales of biofuels. Until now the works on improving it continue. Among those waiting for the changes are, among others, the fuel corporations for which it is difficult to implement the National Indicative Target without the sales support mechanisms.

The Act of the $11^{\text {th }}$ of May 2007 on amendments to the act on the excise tax and amendments to some other acts is among the important legal acts. That document contains the important changes influencing the sector of biofuels. It defines the levels of excise rates for biofuels; as of the $1^{\text {st }}$ of January 2008 the penalty for non-performance of the duties of producers and importers of liquid fuels as concerns the National Indicative Target and the additional financial motivation for vegetable crops producers amounting EUR 45 per hectare of energetic crops that also include crops supplied for the purpose of biocomponents' production was introduced.

Directive 2009/30/EC amending the Directive 98/70/EC covering the specifications of petrol, diesel oil and fuel oils and introducing the mechanism of monitoring and limiting emissions of greenhouse gases from use of fuels in road transport and amending the Directive 1999/32/EC as concerns the specifications of fuels used by inland navigation vessels and repealing the Directive 93/12/EEC is the latest legal act published on the $25^{\text {th }}$ of June 2009. The provisions of the Directive 2009/30/EC make addition of a larger than so far quantity of biocomponents to liquid fuels possible and define the qualitative requirements for engine petrol with bioethanol content of up to $10 \%$ (so-called E10 fuel) and for the diesel oil with the content of methyl ester of up to 7\% (so-called B7 fuel). Simultaneously the Directive provides for the possibility of trading in diesel oil with the ester content exceeding $7 \%$.

So far, according to the Act of the $25^{\text {th }}$ of August 2006 on the system of fuels quality monitoring and control engine petrol could contain up to $5 \%$ by volume of bioethanol or ether in up to $15 \%$ by volume while the diesel oil could contain up to $5 \%$ by volume of the esters. The requirements of the Directive 2009/30/EC will be transposed into the domestic legal system gradually. Currently, works are in progress on drafting the Act on amendment to the act on the system of fuels quality monitoring and control and some other acts implementing the provisions of the Directive 2009/30/EC. The draft was published on the $31^{\text {st }}$ of January 2011 and according to the draft work plan of the Council of Ministers it is planned to be considered by the Council of Ministers during the second quarter of $2011^{12}$.

Poland, after overcoming the legal-financial issues related to production of generation I biofuels (acting according to the assumptions for the period of up to 2020) may be one of the European leaders covering the domestic demand and the demand of other European countries that do not possess sufficient production capacity ${ }^{13}$. 
The European Union represents the position that the effective reduction of $\mathrm{CO}_{2}$ emissions required generation II biofuels (obtained from processing of lignocellulosic plants). The use of waste raw materials unsuitable for production of food is the nature of the generation II biofuels production. The significantly higher quality of those fuels as compared to generation I biofuels as a consequence of which they are more acceptable for automotive industry is also important aspect. The industrial scale production processes have not been developed in a completely satisfying way yet ${ }^{14}$.

The Directive 2001/77/EC of the European Parliament and of the Council of 27 September 2001 on the promotion of electricity from renewable energy sources in the internal electricity market and the Directive 2001/80/EC on the limitation of emissions of certain pollutants into the air from large combustion plants (the LCP Directive) can also be treated as those of influence on conditions of renewable energy power sector development.

The Communication from the Commission COM (2005) 628 Biomass action plan is a document that makes particular reference to the use of biomass in production of solid fuels. It can be easily concluded on the base of that document content that biomass is and will be the priority renewable energy source in the European Union during the coming years. The document specifies the methods for obtaining energy from biomass by, e.g. creating new market incentives for its use and removing barriers to the market development.

The Act of the $10^{\text {th }}$ of April 1997 Energy law is the fundamental document of the domestic law concerning the issues of renewable energy generation. The Act defines the principles for formulation of the national energy policy, the principles and conditions for supply and use of fuels and energy, including heat, principles of operation of energy sector enterprises and the bodies competent for the issues of fuels and energy management.

High importance in supporting the renewable energy sources was attributed to the Regulation by the Minister of Economy of the $15^{\text {th }}$ of December 2000 (amendment of $9^{\text {th }}$ of December 2004). The Regulation concerns mainly power and heat generation from renewable energy sources, including biomass. The Regulation of the 30 th of May 2003 (amendment of the $9^{\text {th }}$ of December 2004) introduced the formula for computation of the share of renewable energy in case of joint combustion. The novella of the Act Energy law of the $2^{\text {nd }}$ of April 2004 defined the minimum level of penalties for non-performance of the duty to purchase or generate energy from renewable sources. Another novella of the Act Energy law of the $4^{\text {th }}$ of March 2005 introduced major changes in the aspect of support to the renewable energy sources. The producers of power and enterprises trading in it and selling power to the end users were committed to present to the Energy Regulatory Office the green certificates or to pay the so-called substitute charge ${ }^{15}$. 
The Rural Areas and Agriculture Development Strategy 2007-2013 (2005), where within the frameworks of the "Support to sustainable development of rural areas" the plants that can be cultivated for energy generation purposes is also important for development of energetic plants production development.

\section{Technological conditions for biomass use}

Technologies using biomass for processing it into power and heat energy are currently among the cheapest and most environment-friendly. However, the volume of available raw materials base (as professional power generation sector, timber industry and private buyers compete for timber from natural forests) and assuring industrial supplies of biomass from field plantations represent the limitation ${ }^{16}$. Straw can be the raw material for energy generation obtained from agricultural areas. According to the computations by Kuś and Faber ${ }^{17}$ the domestic surplus of straw is around 9 million tons of which at least $30-40 \%$ could be used for alternative purposes, including energy generation. Estimating the volume of straw for alternative use it should be highlighted in the areas with scattered structure of agriculture its transport will be unprofitable. On the other hand, large volumes of straw for energy generation purposes could be obtained from areas with domination of large farms that cultivate cereals and rape on even as much as over $90 \%$ of the area of arable land and have small animal production. At such farms around $50 \%$ of straw should be ploughed to assure sustainable balance of organic soil material while the rest could be processed into power. It should also be highlighted that the surplus is highly diversified regionally. Actually, ca. 3-4 million tons of straw could be used for energy generation purposes.

Covering the increasing demand for biomass will necessitate obtaining it from special plantations of multiyear species of plants. Potentially a number of plant species could be used for production of biomass for energy generation purposes while in practical terms their choice will depend on habitat conditions, costs of obtaining reproduction material, equipping the farm with the technical devices and the method for utilization of the biomass. The most important species are the miscanthus, bushy willow, sida hermaphrodita, reed canary grass, giant knotweed and Jerusalem artichoke ${ }^{18}$. In 2007, around 1,0 million tons of biomass was used for power production and around 4,5 million tons was used for heating purposes (converted to dry mass) in Poland. It is estimated that in 2020 the minimum demand from the power sector will be 4,2 million tons of biomass and that of the heating sector 5,4 million tons, which means that the total demand will be around 10 million tons ${ }^{19}$. 
Use of biomass for energy generation has already been mastered in technical scale in the form of direct combustion, joint combustion of fossil fuel with biomass and thermal utilization of biomass combined with its pyrolysis and gasification. In case of popular joint combustion of biomass with coal the wood biomass is the most effective ${ }^{20}$. Technologies allowing joint combustion of biomass with coal in the existing boilers attract high interest from entities of the domestic power and heating sectors. That solution seems the fastest path leading to biomass use in high capacity generating units. In obsolete or inefficient thermal devices combustion of timber or waste timber results in increased emissions of pollutions, including the harmful ones as sooth, poisonous carbon oxide and other chemical compounds. Combustion of solid biomass is not always beneficial from the environmental perspective. Energetic use of the derivatives of solid biomass such as liquid and gaseous fuels is more beneficial ecologically. The development in application of liquid biofuels in combustion engines of mechanical vehicles is particularly interesting ${ }^{21}$. Processes of generating heat from combustion of specific types of biomass particularly those characterised by relatively low humidity (straw, miscanthus, willow, firewood - "naturally" dried) are considered representing the highest efficiency from the energy efficiency perspective ${ }^{22}$. High humidity (even up to 50\%) requires combustion in special boilers in medium and large capacity heating plants. Biomass combustion in traditional central heating boilers requires decreasing its humidity to under $15 \%{ }^{23}$.

Biomass must be processed to become valuable fuel. Only appropriately prepared biomass is the eco-fuel. It is the best solution to expose the straw to atmospheric conditions (especially rain) to wash out the compounds causing boiler corrosion and then to press it. Timber should be chipped and then converted into firing blocks or used for production of pellets. Energy outlays on biomass processing are relatively low and range from 1 to $2,5 \%$ of the energy contained in the raw materials produced ${ }^{24}$.

Raw materials for production of liquid biofuels must also be processed. Rapeseed (the main raw material used for the domestic production of bio-diesel) must be subjected to oil extraction which is next processed by esterification to obtain methyl esters FAME. Cereal grain, on the other hand (raw material for bioethanol production) must be subjected to the fermentation process. The spirit obtained in that way must be dehydrated to allow its use as fuel in the internal combustion engines. First of all raw materials of poorer quality (unsuitable for human and animal feeding) should be used. Use of agricultural products for energy generation represents also a method for using the production surplus. 


\section{Conclusions}

The implemented legal regulations concerning biomass used in renewable energy generation in Poland are a consequence of the necessity to adjust the domestic legislation to the European Union legislation. The EU Directives are of general nature, which means that they leave the Member States a certain extent of freedom in creating the domestic legal standards in that field. The Community law governs a number of important issues requiring transposition into the domestic law. One of the major issues is the stabilisation of multiyear programmes of exemptions from the excise tax for addition of biocomponents to liquid fuels and liquid biofuels.

During the nearest years utilisation of biomass will increase, particularly biomass obtained from land under agricultural use. Currently the agricultural products for which the major directions of utilization are use as fodder or food are the major raw materials for production of liquid biofuels. The increasing production of biofuels results in the real threat for availability of food products and increase in their prices in the global markets. Forest areas are the second source of energetic biomass but their importance will be decreasing. Established for that purpose plantations supplying raw materials for production of biogas or direct combustion (joint combustion) will be the future source for obtaining energetic biomass. Increased use of agricultural biomass requires establishing the chain efficiently linking production, processing, distribution, storage and use of the raw material. The priority function of agriculture is to assure the food safety. The last period confirms the belief that agriculture will play an important role also as the producer of energetic raw materials. Currently in Poland, energy generation from biomass is at the stage of rapid development, but only at the level of small scale energy generation while grid power plants and heat and power plants apply biomass combustion to a very limited extent.

Gradual transformation of agriculture in the direction of non-food use of agricultural products has become an important component in numerous research programmes in both Poland and the European Union. The long list of cultivable plants that could find application in the energy sector was the outcome of that work. Thanks to expanding biomass production from plants cultivated for energy generation purposes social benefits (local limitation of unemployment), economic (including increase of revenues from farms) and environmental (better closing of the $\mathrm{CO}_{2}$ circulation) could be achieved. Biomass is also a limited resource and the situation of competition for the production surface with food production or maintaining biodiversity may occur. Nevertheless the influence of renewable energy (including biomass) on the possibilities for improving the environmental and energy situation in the country should not be exaggerated. 


\section{Notes}

1 Alternatywna polityka energetyczna... (2009).

2 Jasiulewicz (2008).

3 Roszkowski (2007); Roszkowski (2008).

4 Grzybek (2003); Kryk (2010).

5 According to the Directive 2003/30/EC of the $8^{\text {th }}$ of May 2003, that notion encompasses substances of vegetable or animal origin that are subject to biodegradation, originating from products, waste and residues from agricultural and forest production, also of the industries processing their products, as well as the biodegradable part of the industrial and municipal waste.

6 Grzybek (2003); Jasiulewicz (2010).

7 Janowicz (2006); Jasiulewicz (2010).

8 Directive 2009/28/EC.

9 Polityka energetyczna Polski do 2030 roku (2009).

${ }^{10}$ Kołodziej, Jaroszyński (2010).

11 Bielski (2011).

12 Ibidem.

${ }^{13}$ Kachel-Jakubowska, Szpryngiel (2009).

${ }^{14}$ Merkisz, Kozak (2007).

15 Jasiulewicz (2010).

16 Szczukowski, Tworkowski (2009).

${ }^{17}$ Kuś, Faber (2009).

18 Ibidem; Kuś, Matyka (2009).

19 Grzybek (2008).

${ }^{20}$ Roszkowski (2008).

21 Wójcicki (2007).

${ }^{22}$ Roszkowski (2008).

23 Wisz, Matwiejew (2005).

24 Juliszewski (2009).

\section{References}

Alternatywna polityka energetyczna dla Polski do roku 2030. Raport (2009). K. Żmijewski (ed.). Instytut na rzecz Ekorozwoju.

Bielski, S. (2011). Polityka dotycząca biokomponentów paliw płynnych w Polsce w kontekście uwarunkowań prawnych. Polityka ekonomiczna, 166: 48-58.

Communication form the Commission. Energy for future: Renewable Energy Sources. White paper for a Community strategy and action plan, COM(97)559 final (26/11/1997).

Communication from the Commission of 7 December 2005 - Biomass Action Plan COM(2005) 628 final. 
Directive 2001/77/EC of the European Parliament and of the Council of 27 September 2001 on the promotion of electricity produced from renewable energy sources in the internal electricity market L 283/33.

Directive 2001/77/EC of the European Parliament and of the Council of 23 October 2001 on the limitation of emissions of certain pollutants into the air from large combustion plants L 309/1.

Directive 2003/30/EC of the European Parliament and of the Council of 8 May 2003 on the promotion of the use of biofuels or other renewable fuels for transport L 123/42.

Directive 2009/28/EC of the European Parliament and of the Council of 23 April 2009 on the promotion of the use of energy from renewable sources and amending and subsequently repealing Directives 2001/77/EC and 2003/30/EC, Official Journal L 140, 05/06/2009.

Directive 2009/30/EC of the European Parliament and of the Council of 23 April 2009 amending Directive 98/70/EC as regards the specification of petrol, diesel and gas-oil and introducing a mechanism to monitor and reduce greenhouse gas emissions and amending Council Directive 1999/32/EC as regards the specification of fuel used by inland waterway vessels and repealing Directive 93/12/EEC (L 140/88).

Green Paper - Towards a European strategy for the security of energy supply COM/2000/0769 final.

Grzybek, A. (2003). Kierunki zagospodarowania biomasy na cele energetyczne. Wieś Jutra, 9: 10-11.

Grzybek, A. (2008). Ziemia jako czynnik warunkujący produkcję biopaliw. Prob. Inż. Rol., 1: 63-70.

Janowicz, L. (2006). Biomasa w Polsce. Energetyka, 8: 601-604.

Jasiulewicz, M. (2008). Wykorzystanie upraw energetycznych w strategii konkurencyjności regionów. Roczniki Naukowe SERiA, 2: 98-102.

Jasiulewicz, M. (2010). Potencjat biomasy w Polsce. Koszalin: Wyd. Uczelniane Politechniki Koszalińskiej.

Juliszewski, T. (2009). Ogrzewanie biomasą. Poznań: Wyd. PWRiL.

Kachel-Jakubowska, M., Szpryngiel, M. (2009). Analiza perspektyw wytwarzania biopaliw płynnych w Polsce. Inżynieria Rolnicza. No. 8: 47-53.

Kyoto Protocol to the United Nations Framework Convention on climate change made in Kyoto on the $11^{\text {th }}$ of December 1997 (DzU of 2005, No. 203, item 1684).

Kołodziej, A., Jaroszyński, M. (2010). Biopaliwa: aspekty technologiczne, ekonomiczne i prawne. Prace Naukowe IICh PAN, 14: 59-76.

Kryk, B. (2010). Polityka $w$ zakresie odnawialnych źródet energii i wybrane narzędzia jej wspomagania, in: J. Sokołowski, M. Sosnowski, A. Żabiński (ed.). Polityka ekonomiczna. Wrocław: Prace Naukowe UE we Wrocławiu, p. 314-325. 
Kuś, J., Faber, A. (2009). Produkcja roślinna na cele energetyczne a racjonalne wykorzystanie rolniczej przestrzeni produkcyjnej Polski, in: A. Harasim, Przyszłość sektora rolnospożywczego i obszarów wiejskich (63-75). Puławy: Wyd. IUNG-PIB.

Kuś, J., Matyka, M. (2009). Plonowanie wybranych gatunków roślin uprawianych na cele energetyczne w różnych warunkach siedliskowych, in: A. Skrobacki, Produkcja biomasy, wybrane problemy (9-14). Warszawa: Wyd. Wieś Jutra.

Merkisz J., Kozak, M. (2007). Biopaliwa do samochodowych silników spalinowych. W: Biomasa dla elektroenergetyki i cieptownictwa - szanse i problemy (178-183). Warszawa Wyd. Wieś Jutra.

Polityka energetyczna Polski do 2030 roku (2009). Ministerstwo Gospodarki, Warszawa (M.P. 2010, nr 2, poz. 11).

Roszkowski, A. (2007). Energia a rolnictwo, materiały IX Konferencji Naukowej Teoretyczne i Aplikacyjne problemy Inżynierii Rolniczej, 19-22.06.07, Wrocław-Polanica, pp. 261262.

Roszkowski, A. (2008). Biomasa kontra rolnictwo. Inżynieria Rolnicza, 10: 201-208.

Rozporządzenie Ministra Gospodarki z dnia 15 grudnia 2000 w sprawie obowiązku zakupu energii elektrycznej ze źródeł niekonwencjonalnych i odnawialnych oraz wytwarzanej w skojarzeniu z wytwarzaniem ciepła, a także ciepła ze źródeł niekonwencjonalnych i odnawialnych oraz zakresu tego obowiązku (DzU nr 122, poz. 1336).

Rozporządzenie Rady Ministrów z dnia 15 czerwca 2007 r. w sprawie Narodowych Celów Wskaźnikowych na lata 2008-2013 (DzU 2007, nr 110, poz. 757).

Szczukowski, S., Tworkowski, J. (2009). Wybrane aspekty plonowania i wykorzystania biomasy wierzby, in: A. Skrobacki, Produkcja biomasy, wybrane problemy (15-23). Warszawa: Wyd. Wieś Jutra.

Ustawa z dnia 10 kwietnia 1997 r. Prawo energetyczne (DzU 2003 r. nr 153, poz. 1504 z późn. $\mathrm{zm}$.).

Ustawa z dnia 25 sierpnia 2006 r. o biokomponentach i biopaliwach ciekłych (DzU 2006, nr 169, poz. 1199).

Ustawa z dnia 25 sierpnia 2006 r. o systemie monitorowania i kontrolowania jakości paliw (DzU 2006, nr 169, poz. 1200).

Ustawa z dnia 11 maja 2007 o zmianie ustawy o podatku akcyzowym oraz o zmianie niektórych innych ustaw (DzU 2007, nr 99, poz. 666).

Wieloletni program promocji biopaliw lub innych paliw odnawialnych na lata 2008-2014 (M.P. 2007, nr 53, poz. 607).

Wisz, J., Matwiejew, A. (2005). Biomasa - badania w laboratorium w aspekcie przydatności do energetycznego spalania. Energetyka, 9: 631-640.

Wójcicki, Z. (2007). Energia odnawialna, biopaliwa i ekologia. Inżynieria rolnicza, 2: 5-18. 
